\title{
Abandonment and victory in relations with dead bodies
}

\author{
John Borneman
}

Katherine Verdery was the first to make some systematic observations about the accelerated movement of dead bodies in EastCentral Europe following the collapse of the Soviet Empire. She noted that, in this period of political transformation, the corpses of political leaders and cultural heroes accrued certain powers leading to a struggle over appropriating those powers, and to the exhumation and displacement of their bodies (Verdery 1999). Here I wish to consider the modes of appropriation of the power of corpses and offer an explanation for their widespread movement in postsocialist states. This movement, I will argue, is a manic reaction to the death of political regimes and to the sense of abandonment that accompanies this end. Although people may understand this reaction as asserting sovereignty over the dead, it in fact demonstrates the inverse: that the dead govern the living. How and why is it that humans deny being governed by the dead and instead claim victory over their losses? What is the connection between the experience of regime end and the attempts to declare victory through the exhumation and reburial of corpses?

The death of other humans is an omnipresent threat and experience in all cultural landscapes, and after the death, landscapes are marked 
socially by the absence of the person to whom one was attached. Anthropologists have documented the various ways in which all societies try to deal with this absence by inventing peculiar rites and institutions to turn absence into a presence of sorts and a 'good death. The specifically human characteristics of relations to the dead entail both the individual process of mourning and collective funerary rites.

Neither individual grief in mourning nor funerary rites are specific to humans, however. Dogs grieve for their dead owners, sometimes to the point of refusing to live after their deaths, often refusing to make new attachments - a reaction roughly corresponding to our notion of melancholia. Lions are known to smell and lick the dead bodies of members of their own species before eating them. Dolphins appear listless and lose appetite after the death of a member of their pod. Elephants have been observed to cover the dead with leaves and branches, to get highly agitated upon seeing the bones of members of their species and also to revisit the bones of dead relatives. Chimpanzees show complex emotions towards a dead partner, although they seem to no longer care once the corpse begins decomposing. Given the increasingly complex understandings of other species, our notion of human distinctiveness as defined by individual grief and collective rites of separation is insufficient. One must also add that, in contrast to other species, there is tremendous variation within the human species in relating to the dead. The ethnographic record documents endless diversity in modes of proper and improper separation that are sensitive to place and time.

Among humans, we can speak of two radical orientations toward grief and toward funerary rites. As to grief, we have the Freudian distinction between mourning and melancholia, the former being a grieving process of letting go of the lost object, the latter as a grief that refuses to acknowledge the loss and hence holds on to the lost object. As to funerary rites, we can distinguish between eviscerating traces of the dead and preserving them for eternity. These two orientations can, as an initial heuristic, be roughly mapped onto the difference between beliefs in reincarnation or the transmigration of souls and the belief that death is a more absolute end. 
Mourning

eviscerating the dead belief in reincarnation
Melancholia

preserving the dead

belief in an absolute end

In short, there is an elective affinity between mourning, eviscerating the dead and belief in reincarnation, on the one hand, and an elective affinity between melancholia, preserving the dead and belief in an absolute end, on the other. Each of these distinctions breaks down in any attempt to use them as the basis for a typology of types of societies. Cremation and preservation, for example, are often practised simultaneously in many societies. But as radical orientations and affinities, they are nonetheless a useful point of departure.

Before moving to particular cases drawn from my own ethnographic work, let me begin with an unfashionable comparison of culture regions, and acknowledge the rough historical difference between the West and East that corresponds to the extremes of preservation versus cremation of the dead. We might isolate the crucial difference in funerary practices in the symbolism of embalming the body before putting it underground and burning it on a pyre above ground. Burning above ground, it is interesting to note, although regularly practised in Western countries as the burning of effigies, that is, burning substitutes for some disliked figure, is highly regulated if not illegal when practised in the open air. ${ }^{1}$ There is something disturbing in the West, then, about the visualisation of the evisceration of the dead, the fear of contamination through this process, and hence there is a need for control of its public display and acknowledgment. Something like the public secret of prostitution and homosexuality, until recently: accepted as private acts so long as one need not recognise them in front of others.

In England, for example, the Cremation Act 1902 allowed burial authorities to establish crematoria, but the act was amended in 1932 to ban open-air pyres, a practice which in turn was legalised in 2010 if, the court stated, it took place within a structure of some sort. Denmark shares with England a similar legal and popular evolution of the practice; they both now have one of the highest rates of cremation within Europe (73 per cent). In 1892, the practice in Denmark was officially legalised. More recently, however, the framing has been changing. In 2009 as a justification in preparation for the UN Climate Change conference, the Danish association of crematoria 
revealed that fifteen of its thirty-one crematoria proposed recycling waste heat from its ovens into district-heating systems, and that all of its crematoria already profitably recycled scrap-metal parts salvaged from the dead - specifically knee or hip replacements. (Artists, importantly, are barred from using such scrap metal. $)^{2}$

We see here, then, in England and Denmark, some concern with the afterlife, but the concern is framed as the continued utility of dead bodies during and after cremation. This is certainly not to be equated with the strong notion of rebirth contained in the Hindu or Buddhist notion that life continues after cremation through reincarnation. Reincarnation is not merely life after death, as in the Christian or Muslim belief in a rematerialisation of some version of the person in heaven; rather each individual is reborn into another living being - if and until some select few reach nirvana, a state variously imagined as free of suffering and of the desires that produce individual cravings and aversions.

Nirvana is, again, quite unlike the Christian imagination of individual beings reconstituted in heaven or hell, in sites of pleasure and goodness or punishment and evil. Desire does not go away but is either fulfilled or one is punished for it. The belief in reincarnation itself should theoretically be more comforting after a loss. Maintaining that the dead will be reborn, even, perhaps, as younger, healthier people, or in a higher and better status than in previous lives, makes it less wrenching to display the deceased above ground and to let the corporal remains disappear publicly. This is not to neglect that Hindu or Buddhist cremation is part of a series of rites of separation, which ultimately also entail quite emotionally wrenching acts, such as sifting through the remains for bone shards and cracking the skull after the burning, and also often purifying the survivors who had been contaminated by the dead in a ritual.

Hindu and Buddhist funerary rites in fact work through the grieving process to effect the type of separation from the loved object that Freud analysed as mourning, a more radical letting go of the loss than is common in Christian rites. Because the dead person has a future and that future is dependent largely on the accumulated karma of the dead as well as on the performance of the proper rituals by the living, an extreme melancholic attachment to what is lost appears less compelling. A clear East/West mapping of culture area is confounded, of course, by the fact that some Christian sects and New Age groups in the West also believe in reincarnation, as do many Native Americans, for example, the Inuits and other indigenous peoples. 
The point here is that the absence of a strong doctrine of reincarnation in the Semitic monotheistic religions, and thus in the West generally, confronts the individual and groups there with their own stark and difficult-to-accept view of the absolute end of life. Those societies that insist on the dead being dead have a more difficult time with loss, and therefore try, in a melancholic gesture that subverts their ideology of finality, to preserve the dead, most frequently putting their earthly bodies underground. We often talk of 'burying the dead', but putting them underground should be taken as a metaphor of finality rather than a literal overcoming, putting away or putting behind. The crucial point theoretically is that burial underground expresses a desire to preserve or arrest the natural temporal process of decay, but also not to be witness to it. We might investigate the elaborate symbolic forms of modes of preservation in different cultures, and whether these correspond to a melancholic attachment to loss, or in the extreme, to an occlusion of the loss by claiming the ability to govern it.

\section{III}

Why humans in the East and West grieve the dead is not, I suspect, because they are gone, but, on the contrary, because they won't go away. As intersubjective beings, humans do not think their existence alone but experience it in a continuous series of attachments to and separations from others. We carry around within us images of these others, who become internal objects, images in our heads, and remain so even after their deaths or disappearances. The dead remain as memories that appear in dreams and daydreams, and they often appear as the result of projections in uncanny experiences of déjà vu. The fact that the dead are still present confounds the sense of chronological time and social order in any cultural system, but it is especially troublesome in those societies that interpret mortality as the susceptibility to a final death, an exit from the world of the living once and for all. The possibility of life after death and the signs of this afterlife are ubiquitous in both the East and the West, and often take the form of imaginative representations of quasi-humans in liminal states - vampires, zombies, ghosts and monsters, which, although having forms specific to cultural and historical worlds, can nonetheless be interpreted generally as attempts to make sense of and contain the afterlife, this most unknowable of things. 
Whatever the imaginations of death, the decay of the body confronts all human groups with an empirical and inescapable reality, a phenomenon Maurice Bloch intensively explored in Madagascar (Bloch 1971). The process of decay makes dying and dead bodies a particularly appealing site for projection, that is, for religious thought: the attribution of forces and causes to beings wholly outside ourselves. How does one reconcile death with the slow disintegration of the body, with the rot and stink that suddenly appears internal to the body? And how does one deal with the fact that the present decomposition of a dead person is a sign of our own futures? Such contradictions bring forth ambivalent emotions, especially guilt feelings for having been unable to stop the death or arrest the decay, or worse, for having wished for the death at some point, in others words, for having failed the dead or even caused the death.

Such emotions are appropriately called affects, intense feelings that are difficult to bring into language, to euphemise or symbolise, and hence to control. The impossibility of bringing our losses fully into language points to a gap in the symbolic order, something for which there are no words that nonetheless has structuring effects, such as the reappearance of the dead in our dreams and visions as if they were still alive. This eruption of the loss that cannot be symbolised is what Slavoj Žižek (1989: 162) takes as the Lacanian Real - 'the hard core resisting symbolisation [that nonetheless] produces a series of structural effects (displacements, repetitions, and so on)'. Affect might, in other words, be the symptom of the Real, the only manifestation that the Real exists. That is, the reappearance of the dead despite their absence asserts itself over the living, comes unbidden and reveals itself in displaced aggressions and repetition compulsions. Thoughts of the governability of not only the emotions but also of corpses themselves, then, can be understood as attempts to contain affect and reverse an asymmetry in power - to insist that one can indeed control the dead even after it is they who have abandoned us. This insistence is summarised in Žižek's (157) pithy statement, 'In the phallus, loss as such attains a positive existence.'

The refusal to let the dead be dead and to accept our abandonment also has an affinity with the desire to remain young forever, that is, with the denial of mortality and the ageing process generally. Here, again, we might note an old East/West difference: age is valorised in the East but youth is valorised in the West. In the West today there is an extreme reversal of the usual cross-cultural valences between youth and elderly: the youth want to stay that way forever and the elderly now want to be and act like youth. This prolonged 
if not life-long experience of youth, or what we might call a youthwish, places new demands on the ageing and the dead, positioning them as spectres to be contained or denied. The West today seems permeated by a general paranoia about being watched, surveilled or disciplined by omniscient forces and processes external to the individual, something the collapse of a territorially identifiable enemy (the USSR) and the event of $9 / 11$ have accentuated. Ageing and death circle this youth-state like vultures do their prey. Some of the popularity of the Foucauldian paradigm of discipline can be attributed to this increasingly empowered youth or youth-wish, a prelapsarian state of being located in a paranoid position. Also symptomatic are the well-funded and highly publicised life sciences that continually evoke promises of the extension and reinvigoration of life and feed fantasies of individual omnipotence.

In this spirit of the age, the notion that the dead are internal objects is less appealing to think than the assumption that they are merely external beings that can be embraced or discarded at will. Today expressive culture, especially film and stage drama, routinely stages conversations with the dead as beings largely within ourselves, but art takes liberties with thought that are too dangerous for the popular consciousness - and, unfortunately, for much social science. Popular resistance to the notion of dead as internal objects comes in the form of avoidance of reality-testing and in an obsession with the idea of agency. Acknowledging the dead as internal objects, the alien we have implanted within us, rather than an external reality to be disposed of, would force a level of verification of our perceptions, where we try, to quote Sandor Ferenczi (1926: 318), to 'verify our inner and outer experience by analogies taken from both points of view. The oscillation between processes of internalisation and externalisation, or introjection and projection, might enable us to modify what notions and images we hold of the dead in our heads as we translate their presence back to ourselves and to others. Without an appreciation of this possibility of modification of the images in our heads, we engage in excessive reification and fetishistic thought by imputing to external others - to the dead, to language, to disciplinary regimes - ideas and imaginations that belong to ourselves alone.

\section{IV}

Let us return now to the question of why the dead reappear, and examine some theoretical positions in light of the empirical cases 
of the former Soviet Union, a place and people who straddle East and West, and its former satellite East Germany. In the Eighteenth Brumaire, Marx famously defined the dead as 'nightmares' that weigh on the brains of the living, consistent with his interest in liberating humans from all past investments in order to accelerate historical change and produce a more perfect world (Marx 1994). Communist leaders in the Russian Revolution interpreted Marx's dictum to mean to liberate the people from the Czarist regime by eviscerating its material remnants - in addition to the physical bodies, the architectural and religious symbolism of its rule - and, six years after seizing power, to hedge their bets, preserving the memory of the Revolution by mummifying Lenin's body and placing it in the centre of the Kremlin. After toppling the Czar in 1918, the new rulers were rumoured to have killed the Romanov family, the Czar and his wife and children, and then to have disposed of their bodies. ${ }^{3}$

The Bolsheviks conjoined the two metaphors that Marx evoked: the Czar as appearing in a nightmare, located inside our heads, and the Czar as an external weight, on top of the brain. As a nightmare, he is internal to the living, a dream that comes unbidden to the unconscious in the night; as a weight on the brain, he is external and can be physically removed. The mummification of Lenin in 1924 can be interpreted along these latter lines, as an attempt to place a material weight on the Revolution, to bind its future to its origin by means of the permanent presence of the dead leader: the Cult of Lenin. In any event, the Bolsheviks chose physical removal for the Czar and tried to erase any material trace of him and his family, and any information about the disposal of their bodies. Perhaps their intent in physically removing one weight (the Czar) and placing another (Lenin) on the brain was indeed to prevent the return of the Czar as a bad dream, that is, to prevent his effects in the unconscious. The point is, they did not reject understanding of the dead as nightmare: a fantasy imagined while asleep and then projected onto the world, which then returns to the psyche as a disturbance or horror. This ambivalence about the presence and use of the dead was in tension with the presentist goal to govern in the name of a single, undivided authority, the Party, that recognised no ambivalence about its past while itself becoming a monstrous death-producing apparatus. Working within the paradigm of total sovereignty over the future of the entire society and the state apparatus, the Party located itself as the phallus, the positive existence of the losses that the Party accumulated and denied. In other words, the Party became an image internal to the person, part of the nightmare. 
During the Soviet period, in the space of so many unknowns about the Czar and his family, rumours abounded of sightings. What is significant here is that the masses engaged in collective fantasies of the missing bodies of leaders of the old regime at the same time as the Soviets suppressed the commemoration of the many 'ordinary' dead from the horrific events of early Soviet rule - between 23 and 26 million deaths from the Civil War of 1914-23; another 10 million in the next decade from Stalinist collectivisation, purges and famine; another 26 million deaths from the Great Patriotic War, 1939-45. Lacking a supportive landscape of memory, a public to feed back to the individual the legitimacy of his or her mourning, most people actively collaborated in this suppression to sustain the illusion of the non-existence of the dead. As Katherine Merridale writes, 'Widows or children of purge victims might well be obliged to denounce their disgraced relative, and this not once, but repeatedly in everything they did for the rest of their lives'; they at the same time preserved 'their private memories for years afterwards' in the form of whispered family secrets (Merridale 2001: 75, 66).

The preservation of private memories of the dead in the face of state suppression of private grief was true of all East European socialist regimes. In the early Soviet period the entire state apparatus aimed to replace mystical, religious, emotional burial rites with a 'secular, scientific cremation' (Merridale 2001: 71) and an aseptic 'atheist funeral'. While the state was relatively successful in the replacement of birth and marriage rituals with secular substitutes, the masses stubbornly hung on to their superstitions and elaborate death rituals well into the 1960s. Meanwhile, the state held elaborate yearly ceremonies on the anniversary of Lenin's death of martyrs of the Revolution and rites to commemorate the military heroes of the Great Patriotic War. Merridale concludes, 'commemoration of the war was a near-sacramental act, [and] militarism was not identified with loss, but with triumph' (78). ${ }^{4}$

In retrospect, then, getting rid of the material remains of the former regime did not much liberate the Soviet regime, which took over the more brutal aspects of the Czar's regime and perfected them. After the collapse of the Soviet Union in 1991, the recovery of those bodies became a new media obsession, often with the suggestion that the unjust death which the Czar and his family had suffered might now take revenge on the living and return the lineage to power. Marx's theory of liberation from the dead should warn us that the stronger the wish for liberation from the dead the more tightly projections of the past may shackle our present. 
The Marxian narrative of liberation from the dead is taken up in anthropology by Claude Lévi-Strauss in Tristes Tropiques. Although uninterested in the question of either liberation or historical change, his study of ideology and the displacement of truth produced some acute and relevant insights. After reflecting on the nature of religion among Amerindian tribes in Brazil, he reached the conclusion that religion is a 'smokescreen, [which] on the level of religious thought, conceals, embellishes or justifies the actual relationships which prevail among the living' (Lévi-Strauss 1974: 246). His interest in getting rid of the smoke to see the structure eventually led him to a remarkable formulation, in The Savage Mind, about the different modes of addressing the dead - of their governability through rites of mourning and rites of commemoration.

Mourning rites, he argues, transport the present into the past. By contrast, commemorative rites 'transport the past into the present. [They] recreate the sacred and beneficent atmosphere of mythical times - a "dream" age ... and mirror their protagonists and their high deeds' (Lévi-Strauss 1966: 314). The purpose of commemoration in transporting the past into the present is clearly to secure a seamless repetition of that past (albeit in a transformed state and context); the revisit is a fantasy of unregistered loss and unbroken unity with ancestors in a mythical time. By contrast, mourning, he argues, goes in the opposite direction, seeking to return to the past rather than to bring the past into the present. Mourning rites 'guarantee that men who are no longer among the living will be converted into ancestors.

The implication is that, whereas commemoration keeps the past alive by incorporating the dead into a myth in the tragic mode, mourning rites - conversion of the dead into ancestors - constitute an efficacious overcoming of the dead's hold on us by taking us back to a past that is acknowledged as separate from our own time. In other words, the dead are an irrevocable loss that, if converted into ancestors in this mourning rite, promise a type of closure. Mourning, therefore, by staging events that place the past in the past, differs from commemorative rites that secure a repetition of the past by bringing it into the future.

In Political Crime and the Memory of Loss, I draw attention to this difference between mourning as 'events of accountability' and commemoration as 'rites of repetition', which is homologous to Freud's distinction between mourning and melancholia (Borneman 2011: 3-32). Mourning, as he defined it, is a 'reaction to the loss of a loved person, or to the loss of some abstraction which has taken the place 
of one' (Freud 1917: 243), which entails letting go of the lost person, object or event. A proper separation allows for the development of a self worthy of life and new attachments. Melancholia, which grows out of the same loss, is a reaction of self-reproach that keeps the dead alive, entailing a refusal to acknowledge the loss as irrevocable and therefore foreclosing new attachments. While this distinction has proven immensely productive theoretically, there are, as many scholars have maintained, different degrees of letting go and holding on, and therefore a large range of grieving practices partaking of elements of both of these poles.

Subsequent research has questioned the very possibility and desirability of exchanging one loved object for another. Along these lines, Freud's model is interpreted as assuming the health of an ego that is fundamentally narcissistic and intent only on overcoming loss. To be sure, the presence of dead spirits across cultures makes it doubtful that the conversion of the dead into ancestors is ever complete or permanent, but such figures also suggest that mourning work involves a third subject. That is, mourning is not a solipsistic and self-referential act but requires the mediation of another relationship with an imaginative figure. Along these lines, mourning rites could be seen as Sisyphean: stalling devices that attempt to prevent the fairly inevitable return of a mythical past in the future. If mourning rites in fact intend to release us from the past, they most frequently fail to effect this release, although they still may effect a transformation of the loss. Commemorative rites take into account this failure in advance, displacing the struggle from one over whether to commemorate to one over the form commemoration should take, that is, the form in which the past returns and maintains a presence in the present.

It is worth asking what more or less efficacious conversions of the dead into ancestors might look like, and if some forms of revisiting the past are more transformative and more open to futures than others. For one, an effective conversion of the dead into ancestors does not mean that the attachments to the dead and lost objects leave no traces, a point that Freud himself addressed and clarified in later work. In The Ego and the Id (1923: 29), for example, Freud explicitly insisted on the permanent traces left by losses, a point Laplanche (1999) has made central to his work on Otherness. Freud conceptualised the healthy ego not merely as an autonomous object free to love but as always 'a precipitate of abandoned object-cathexes'. In short, our losses remain with us as accumulated internal objects, which, in the case of melancholia, lead to an identification with the dead. For the melancholic, the lost person is then 'transformed into 
an ego-loss' (Freud 1917: 249), which leads either to a reaction of reproach directed at oneself (depression), or alternatively to mania, assertions of victory over the loss without, however, adequately understanding what it is one has lost.

The question of our relation to the dead, therefore, always turns around the kinds of attachment to lost objects once grieving begins. In mourning that effects a transformation of the loss, the spirit of the dead - the affect of our past attachment - is incorporated into our ego in a way that does not attack it but instead enables a changed understanding of our own temporal existence; the dead in this vision occupy a lost world in which we no longer live and which we have abandoned. The presence of the dead would be remembered as ancestral, prior in time, and not invoked as a living fetish - creating illusions of a determinative presence inherent in the lost objects of our attachment. We would not, then, attribute causality to the dead as spectres outside ourselves, but nonetheless admit their power over us, which arises solely from our necessary internal reckoning with the experience of loss, and the feelings of powerlessness and abandonment that accompany it.

\section{V}

Melanie Klein (1948) argues that at moments of significant loss or separation we tend to return to a state of anxiety as a result of fear of the loss of our nurturing, loving, caring, comforting (what she simplifies as 'good') internal objects and the threat of being overwhelmed by our threatening, frustrating, punitive, persecutory (what she simplifies as 'bad') ones. Our fear of persecution by the punitive objects in our head, while at the same time our longing or pining for the nurturing ones, activates in us what she calls the 'depressive position'. This position is a significant achievement in the development of a child, and is possible only when the child comes to affirm the ambivalence of its experience. Acknowledging ambivalence, the child might begin to comprehend objects (persons, things, ideas) in the world no longer as divided into discrete good and bad qualities but as containing within themselves both good and bad.

The balance achieved early on between the two kinds of objects is unstable, and this instability, often marked by a denial of ambivalence, continues to haunt the adult subject. Freud initially explained that as we grow up we internalise images of those to whom we 
develop attachments. Klein elaborates how these internalised images constitute a rich inner world of relations, how they are constantly in interaction with the outside world and with one another. One way in which we verify our perceptions is to confront these inner objects with the outside world in order to arrive at a sense of reality, sometimes called 'reality-testing', which provides the basis on which we communicate with others. If the testing goes well enough, we mature and our anxieties do not develop into pathologies, that is, into harmful obsessions and compulsive repetitions. Anxiety about the corpse manifested in the movement of dead bodies is one such repetition.

In moments of the transformation of authoritarian regimes, new orientations must be found in the face of a loss of leaders and delegitimated normative conventions (Borneman 2004a). Klein would argue that the extreme anxieties of this transformation make it likely that we regress to a 'depressive position' in which we fear that our nurturing and comforting inner objects will be overwhelmed by our persecutory ones.

One reaction to this position is indeed depression (a strong version of Freud's melancholia, but where the persecutory objects overwhelm the comforting ones), the other is a manic defence. Such a defence relies on idealisation of the lost object as well as denial of this loss. Transformations from authoritarian regimes entail losses of those sets of authority figures and symbols to which one has been ambivalently attached. Mourning, as opposed to this manic defence, is possible only if one has sufficiently strong nurturing and loving internal objects capable of allaying the fears of loss and abandonment, or of alleviating the guilt for having participated in or even created the loss.

Authoritarian regimes tend to demand forms of complicity in the crimes of their rule. They rely on fear and persecution to secure acquiescence and, through the arbitrariness of their persecutions, cultivate paranoia in the public sphere. At the individual level, evidence for the dominance of threatening objects is the increased prevalence of what clinical psychiatrists call splitting and borderline personalities, characterised by alternating extremes between idealisation and devaluation, and frantic attempts to avoid abandonment. My contention is that the frenzied exhumation and reburials following the collapse of the Soviet and East-Central European regimes represent a collective manic defence: an idealisation of former leaders as well as a refusal to accept that they were in fact gone. 
Is the movement of the dead bodies of the Romanov family the unfolding of a manic defence against loss, the first loss being of the Czarist regime, the second of the Soviet? It was a Bolshevik execution squad of ten men that executed Czar Nicholas II, his wife, Alexandra, the couple's five children and four attendants on 17 July 1918, an event that ended Russian imperial rule and presaged an extended period of Soviet state brutality against its own citizens. Subsequent discourse about the event has assumed that the communists murdered the Romanovs, though there has always been some disagreement about the details of their deaths. What remained most unresolved, however, was the status and placement of the missing bodies. What happened to the imperial remains?

The scientific story of these remains begins in 1979, sixty-one years after the event, when a small group of scientists found, secretly, in the Ural mountains, the disintegrating skeletons of nine people, including three children. This finding was kept secret until 1990, however, and only made public as the USSR neared its own disintegration. DNA evidence subsequently seemed to match these remains with Romanov DNA, but many people refused to believe the evidence, most prominently some Romanov descendants, who wanted to reinstate the monarchy, and the Russian Orthodox Church, which had idealised the Czar and later, in the year 2000, even canonised the entire family. Both the Church and the imperial family supported an alternative version of the story, that the Romanov remains had been disposed of elsewhere in the same forest but destroyed beyond recognition - a very discomforting fantasy that combines a wish for annihilation, a persecutory position, with an idealisation of the dead.

From the time of the killings, stories swirled: about moving the boxed evidence of remains to Venice, Italy, hiding the remains inside a wall at the New Martyrs Russian Orthodox Church in Brussels, missing evidence, newly uncovered topaz jewels, scraps of clothing and bone fragments, official denials and previously undisclosed findings, judicial and lay investigations, uncannily specific details such as the movements of trucks and soldiers around mysterious dead bodies near the Ganina Yama mine during the night of their deaths, vehicles getting stuck in mud and dousing bodies with sulphuric acid and gasoline before burning them.

The details of these stories turn around a specific tension: the desire to find a 'final grave', or, alternatively, to suspend the end so as to preserve the lost figure as ideal, which amounts to an idealised 
acknowledgment of the loss. Much the same kind of tension can be found in most other cases of such missing bodies when the political body is in a moment of radical transformation: for example, in the insistence in the USA after being driven from Vietnam in 1975 that American bodies, living and dead, were missing and had been left behind, and in the bizarre movement of Eva Perón's remains between Madrid, Milan and Buenos Aires. It is also the story of transformation from socialism told about Hungary by Susan Gal (1991) in 'Bartok's Funeral' and about East-Central Europe by Katherine Verdery (1999) in The Political Lives of Dead Bodies. I myself told an ironic version of this story in Death of the Father: the movement of the remains of King Frederick II from Baden-Württemberg to rest surrounded by the graves of his thirteen dogs in Sanssouci in Potsdam, near Berlin (Borneman 2004b: 67-8). Verdery claims to explore how dead bodies 'animate' or 'enchant' politics. More precisely, though, her concern is not with how or why dead bodies, specifically, are animated; rather she examines how politics views the materiality of dead bodies as a site for possible enchantment. She asks how the material dead body can be animated and appropriated for more narrowly conceived political ends (e.g. mobilisation, party or national identification, ideological positioning).

The search for meaning through death is the conundrum Walter Benjamin explored when he wrote, 'Death is the sanction of everything that the storyteller can tell.' The end writes the beginning and the middle of the story to create an interpretative ordering of events of what had happened. Only the end can finally determine meaning and close the story as a signifying totality (cited in Brooks 1984: 23). There is a fear of and struggle over this closure, and hence a motivation to defer the end in an active process of continuous discursive reworking of the stories.

At another level, however, this deferral of meaning in time through the movement of corpses supports my contention that we understand it as a manic defence against loss. In the example of the Russian Czar, the investment in his body - both making it disappear and wishing for its return - is a reaction to the loss of the symbols of an old regime. It expressed the ambivalence about this loss, the love and hate for the old regime. The extreme attempts to hide the family's remains are defences against the feelings of self-reproach and guilt that accompany significant loss, specifically for also having wished this death. This mania is marked, to cite Klein (1948: 351), by 'the desire to control the object, the sadistic gratification of overcoming and humiliating it, of getting the better of it, the triumph over it'. The 
attempt to triumph over the lost object, the Czar, his family and his regime, is a reaction to fears of revenge for having been complicit in the murder of the ruling family; the lost object turns into a persecutor and, as was evident in the development of the Soviet regime, the new rulers became possessed by a general paranoia about internal and external enemies.

\section{VII}

In this final section, I remain with the Soviet and East-Central European socialist world and focus on the status of the body of Vladimir Ilich Lenin and his icon, and on the Lenin cult outside the Soviet regime. What was the meaning of his icon in one of the former Soviet satellite states, the former GDR (German Democratic Republic)? My own ethnographic research there began in 1982. In 1990 the GDR dissolved and was integrated into West Germany (the FRG or Federal Republic of Germany).

First, as I mentioned, Lenin was mummified after his death in 1924 and put on display in a special crypt in the Kremlin. Throughout the Soviet Empire, icons of Lenin proliferated after his death, consciously supported by the regime, and, after 1945, Soviet bloc allies in Eastern Europe put up public statutes of and named streets after him in all major cities. The mummification was, then, not only about deferring his end but also about commemoration: proliferating images to ensure his continual presence.

Nina Tumarkin, in her excellent book on the subject, argues that the Soviet cult of Lenin was integral to the legitimation of the postrevolutionary regime: 'The cult served the needs of the Soviet state and indeed, as a standardised complex of activities and symbols, was a government and party enterprise concocted for the delectation of the untutored masses.' Yet, she also attributes the cult's success to the 'pull of the irrational in the formation of Soviet political culture ... molded by precisely those elements of old Russian culture that Lenin so desperately sought to destroy' (1997: 3). That is, she attributes to ritual the power of being able to tap into the deep cultural roots of Russian mysticism. Lenin, in part through his mummification, was turned into a 'harmless icon' (1997: 87, 90, 105, 127), modelled after the Byzantine practice of the production of icons of saints for identification and distribution, and the creation of 'icon corners' for saints in private homes. The icons, Tumarkin stresses, were not wor- 
shipped but served merely as vehicles through which saints (or Jesus or Mary) could keep in contact with this world.

Many Lenin statues were installed in prominent public places in the GDR, though authorities there were never able to create the same depth of identification with Lenin as were Soviet leaders. I want to focus on the most prominent of these, the 18-metre-high Lenin icon that stood at Lenin Platz on Leninallee in East Berlin. Throughout the 1980s I often walked past this statue, and never once did someone comment to me about it. Although overwhelming the square where it stood, the statue was, at least by the time I began fieldwork, pretty much unnoticed. I suspect that for most people it was simply a background visual across from a well-visited park.

After the opening of the Wall in November 1989, those who took charge of dissolving the GDR and the unification process opposed the prominence of this monument to Lenin - proud, towering, revolutionary - on an everyday street in the new centre. There was at the time a general desire by the West Berliners and West Germans, and a large group of East German supporters, to eliminate signs of the Soviet occupation and to return the territorial-political boundaries of the East to their pre-1945 lines. Streets and places were renamed. Even the names of those that celebrated Klara Zetkin, Rosa Luxemburg and Karl Liebknecht, German heroes who predated the occupation, sparked contentious debate. The intent was to reverse history in the East generally, to unwind it (called 'die Abwicklung') and return to the time before the East had become part of the Soviet Empire (Borneman 1991).

The East German playwright Heiner Müller, whose reputation as independent of the regime was never questioned, even after the Wall came down, seemed to capture the spirit of the times in his many interviews. He often uttered aphorisms, and one I particularly liked went: 'Lenin hat gesagt, "Vertrauen ist gut, Kontrolle ist besser." [Lenin said: Trust is good, control is better.] Stalin hat gesagt, "Kontrolle ist gut, Verdrängung ist besser." [Stalin said: Control is good, repression is better.]' And that indeed fitted the Zeitgeist in the early 1990s; in order to repress the past, one had to get rid of the symbols that signified it, among which the Lenin icon was one of the most prominent. Hence this Lenin was decapitated and removed. The Demontage (disassembly) of the icon is one of the most dramatic images of the end of the socialist era, as the head was separated from the body, and the body slowly suspended from a crane during its removal, hovering over socialist-realist housing blocks. 
Four years later, in 1995, an East German who had won a competition to make a film about Ostalgie (nostalgia for the East) contacted me about narrating parts of the film. East Germans had at the time little authority to narrate their own history, so it made sense to ask an American who had done research there and was not really tainted by the regime to talk about the former East. The director's vignettes included an automobile race with souped-up Trabbis - the small state-produced cars with lawnmower-like engines - and a party at which appeared socialist authorities - such as Lenin, Trotsky, Stalin, Ulbricht, Gorbachev. The vignette I was involved in was called 'Lenin came from Warsaw'. It drew on the irony that the man who played Lenin at these parties was a Pole from Warsaw. I was to explain what had happened to the Lenin statue. After asking around, the director determined that it must have been dumped in some remote site in the forest in Köpenick outside Berlin. Armed with only a three-yearold photo of a reassembled Lenin lying flat on his back in a forest behind an unmarked gate, the director, her film crew and I drove to the Köpenicker forest.

The forest contained several large camping places. We drove into a few. Everybody we met was suspicious of us, and nobody was willing to give us directions. We wandered around for some time before finding an unmarked gate next to a sign that said, 'Eintreten verboten' (To enter is forbidden). We took that road anyway, eventually running into a second unmarked gate, with a large boulder blocking it. Behind the gate was a huge mound of dirt that resembled unexcavated Aztec and Mayan temples I'd seen in Mexico and Guatemala. Under that mound was Lenin, now fully grown over with wild grass, only two small spots of his granite nose sticking out, reputedly the result of efforts by another American to uncover the bust.

For the film, I interpreted this burial as a fear of the power of the icon to mobilise Ostalgie, a fear of a melancholic holding on to the past of which Lenin was a symbol. In Russia at the time there was a debate about whether to remove the Lenin mummy from Red Square in Moscow. The new Russian leaders feared that the absence of the real Lenin (statue) might lead to a legitimation crisis. For the country's leaders, in Berlin the icon was too powerful to leave around, in Moscow the mummy was too powerful to bury. More specifically, the fear of Lenin's icon in East Berlin had to do with ongoing efforts to correct the past in the East, to make people repent and roll back time. The demand to repent for the past foreclosed a process of mourning. In a similar way, Germans after the Second World War faced a demand to repent. Along with submitting to occupation by 
four foreign powers, this demand made it difficult to assume responsibility for the crimes of the regime and admit complicity in them while at the same time mourning their own losses. A potential Lenin resurrection in Berlin might have mobilised some people to resist the efforts of the new authorities to wind down and reverse history.

At the time, I did not interpret the popular wave of Ostalgie to be nostalgia for a return to the past. Instead, I thought the Ostalgie celebrations were mourning rites, attempts to say goodbye to the past, to give it the proper and joyous burial that had been denied these objects of loss in the rush to German unification.

In retrospect, what has happened between the conflict between the three modes of dealing with the past: repression, mourning and melancholia? On the one hand, there is a strong if small group of East Germans who resent and resist this erasing of history, who empowered themselves through the courts (for example, suing officials who fired them because they worked for the Stasi), and reclaimed property they claimed was improperly returned to former owners. They have also pressured museums to change their representations of the GDR period. The attempt to repress the past and roll it back has strengthened their resolve to hold on to it. In this sense, they are in denial of their loss and, if not depressed, themselves engaged in a manic response.

On the other hand, however, a far larger group of East Germans have taken full advantage of the new opportunities that capitalism and West German democracy offer, remodelling their cities and apartments with federal subsidies, travelling abroad to places formerly not allowed, not wanting to be much bothered with the albatross of a socialist past. That reaction means neither denial, repression nor forgetting, however. Even this group has been unable to avoid that past, as it continues to see the dead in films and museum exhibits, and all the political parties seem periodically beset by well-publicised scandals that demand a fuller reckoning with the past leaders.

An increased level of trust in social relations and in the politicaleconomic order generally is a key condition of democratic authority. This trust seems to me characteristic for most residents of Germany today, which suggests that they can relate to the dead without awakening great anxiety. They need not declare governance or victory over them; their bodies are for the moment decomposing without any attempt to reverse the process. This also implies that the attempt to repress the past - to resort to Stalin's dictum, control is good but repression is better - was unnecessary for most Germans. However, some of the smaller groups in the former East Germany who had 
initially engaged in Ostalgie seemed in fact to have repressed their loss. For them, Ostalgie parties, which might have served to acknowledge the loss, had the perverse effect of strengthening the hold on the past. Holding on to the past was also often accompanied by selfreproach, a further attack on and weakening of an ego made vulnerable by the dissolution of East Germany as a political-social order. In the future, such self-reproach makes its members susceptible, in the event they experience another radical transformation of authority, to an assumption of the 'depressive position' and open to another manic reaction to loss. In that case, the dead may again assert control over the living, as internal objects that can eliminate the ambivalence that accompanies loss.

\section{Notes}

1 Burning in effigy is also practised in Eastern countries, and the popular associations are similar to those in the West. In India, what is often added to the figure that is burned is a garland of shoes placed around the neck: an ultimate impurity associated with leather (the hide of dead animals, touched and prepared only by untouchables) and with the feet (the mythical site of the origins of untouchables). I thank Kartikeya Saboo for this tip.

2 See Davies and Mates 2006: 162-5; 'Body heat: using corpses for greenery may be a step too far', The Economist, 6 August 2009 (www.economist. com.node/14191268, accessed 21 November 2010).

3 Much of this account of the Czar's end is taken from Massie (1996) and Radzinsky (1993).

4 How this loss is addressed in the post-Soviet period is not the subject of this chapter, but an important advance is made by Serguei Oushakine (2009).

\section{References}

Bloch, M., 1971, Placing the Dead: Tombs, Ancestral Villages and Kinship Organization in Madagascar (Waltham, MA: Academic Press Inc.).

Borneman, J., 1991, After the Wall: East Meets West in the New Berlin (New York: Basic Books).

Borneman, J., 2004a, 'Introduction: Theorizing Regime Ends', in J. Borneman (ed.), Death of the Father: An Anthropology of the End in Political Authority, pp. 1-32 (New York: Berghahn Books).

Borneman, J., 2004b, 'Gottvater, Landesvater, Familienvater: Identification and Authority in Germany', in J. Borneman (ed.), Death of the Father: 
An Anthropology of the End in Political Authority, pp. 63-103 (New York: Berghahn Books).

Borneman, J., 2011, Political Crime and the Memory of Loss (Bloomingdale, IN: University of Indiana Press).

Brooks, P., 1984, Reading for the Plot: Design and Intention in Narrative (New York: Knopf).

Davies, D. and L. Mates (eds), 2006, Encyclopedia of Cremation (Aldershot:Ashgate Publishing).

Gal, S., 1991, 'Bartok's Funeral: Representations of Europe in Hungarian Political Rhetoric', American Ethnologist 18(3): 440-58.

Ferenczi, S., 1926, 'The Problem of Acceptance of Unpleasant Ideas: Advances in Knowledge of the Sense of Reality', International Journal of Psycho-Analysis 7:312-23.

Freud, S., 1917, 'Mourning and Melancholia', in The Standard Edition of the Complete Psychological Works of Sigmund Freud, vol. 14, pp. 43-58 (London: Hogarth Press).

Freud, S., 1923, The Ego and the Id, in The Standard Edition of the Complete Psychological Works of Sigmund Freud, vol. 19, pp. 12-66 (London: Hogarth Press).

Klein, M., 1948 [1940], 'Mourning and Its Relation to Manic-Depressive States', in The Writings of Melanie Klein, 1921-1945, pp. 125-43 (London: Hogarth Press).

Laplanche, J., 1999, 'Time and the Other', trans. L. Thurston, in Essays on Otherness, ed. J. Fletcher, pp. 234-59 (London: Routledge).

Lévi-Strauss, C., 1966, The Savage Mind (Chicago: University of Chicago Press).

Lévi-Strauss, C., 1974, Tristes Tropiques (New York: Atheneum Books).

Massie, R., 1996, The Romanovs, the Final Chapter (New York: Balantine Books).

Marx, K., 1994, The Eighteenth Brumaire of Louis Bonaparte (New York: International Publishers).

Merridale, C., 2001, Night of Stone: Death and Memory in Twentieth-Century Russia (New York: Viking, 2001).

Oushakine, S., 2009, The Patriotism of Despair: Nation, War, and Loss in Russia (Ithaca, NY: Cornell University Press).

Radzinsky, E., 1993, The Last Tsar: The Life and Death of Nicholas II (New York: Anchor Books).

Tumarkin, N., 1997, Lenin Lives (Cambridge, MA: Harvard University Press).

Verdery, K., 1999, The Political Lives of Dead Bodies: Reburial and Postsocialist Change (New York: Columbia University Press).

Žižek, S., 1989, The Sublime Object of Ideology (New York: Verso). 